Q

11

W32

. 13

UC-NRLF

||||||||||| || ||||||||||||||||||||||||

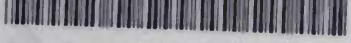

B $3084 \quad 059$ 


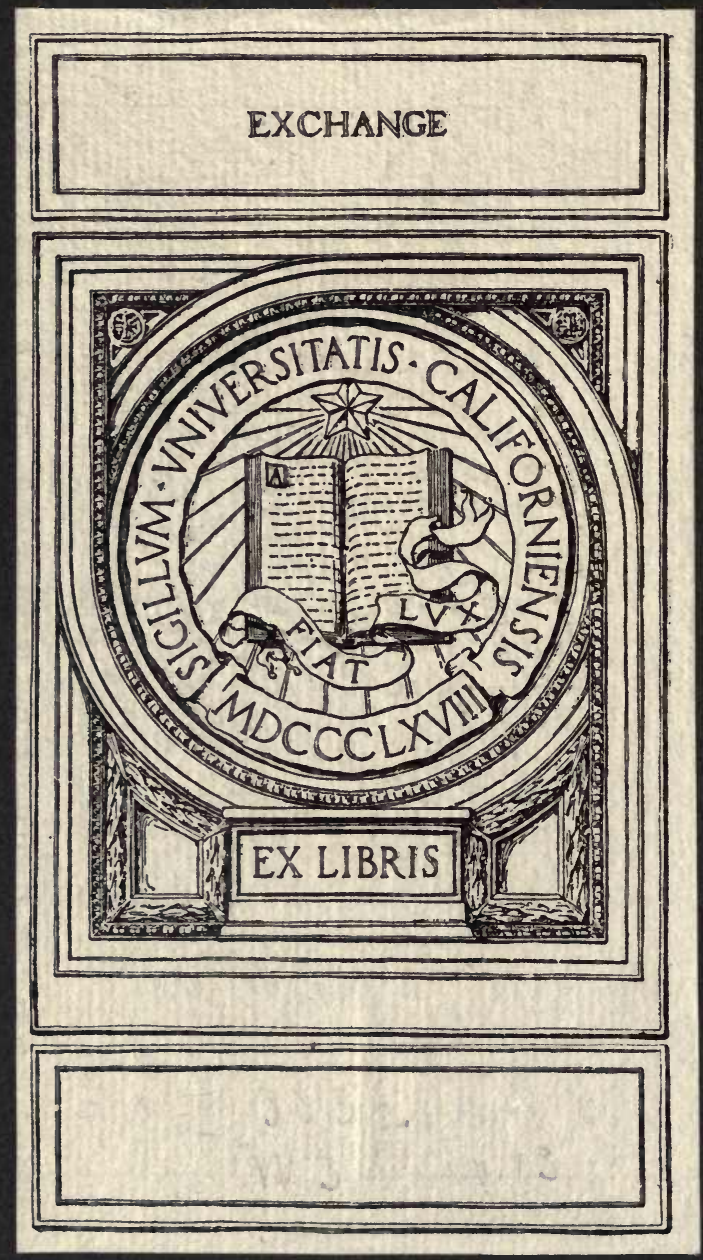





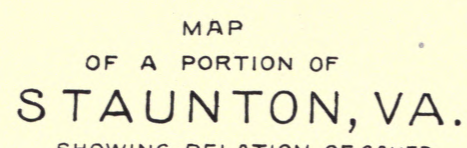
SHOWING RELATION OF CAVED AREA TO THE STRIKE AND DIP OF LIMESTONES BY

E.M.KINDLE AND P.V. ROUNDY SCALE

q $100 \quad 200300400 \quad 500$ FEET
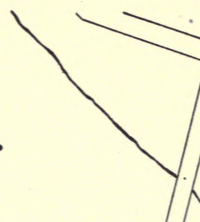

i
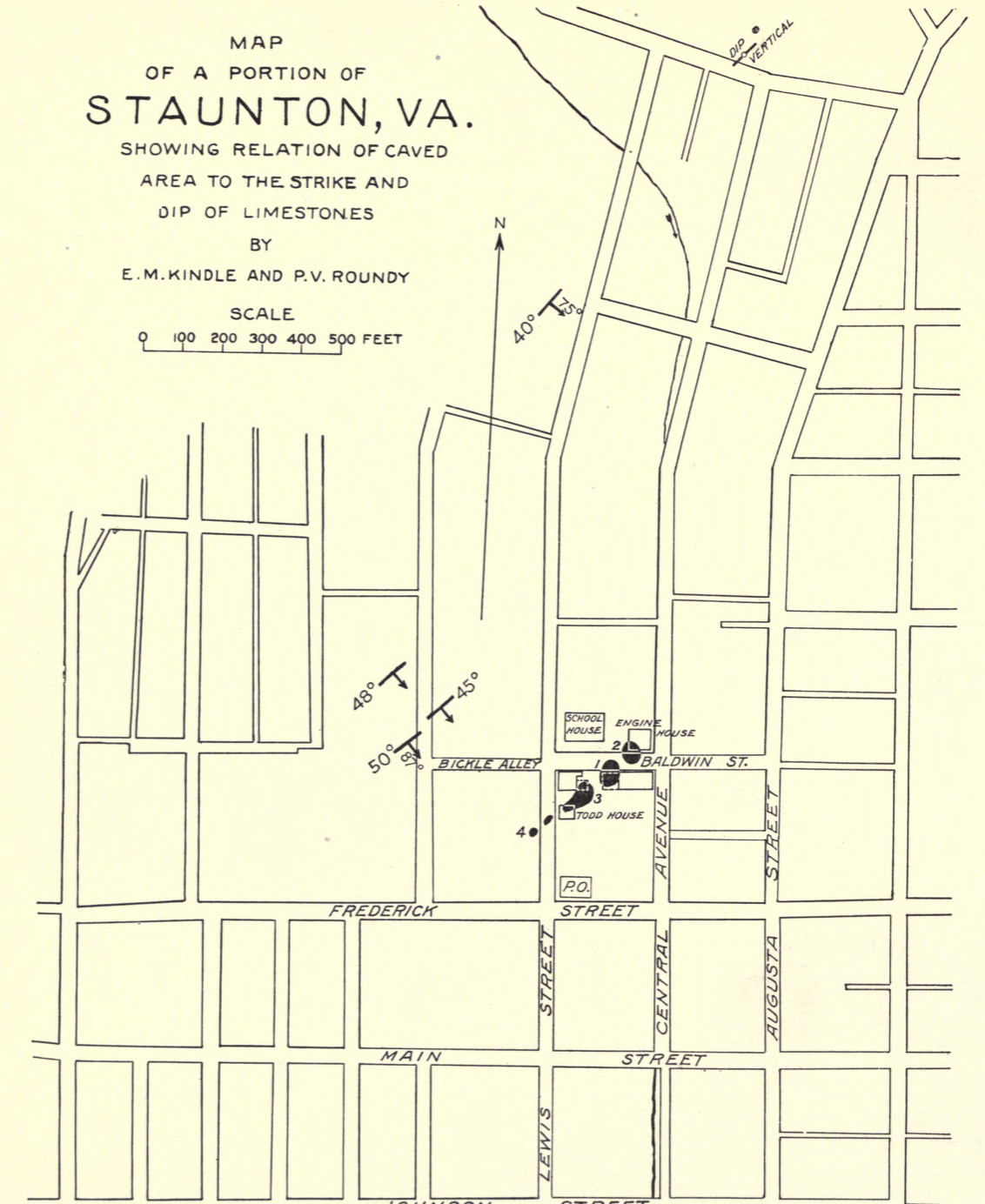

FREDERICK
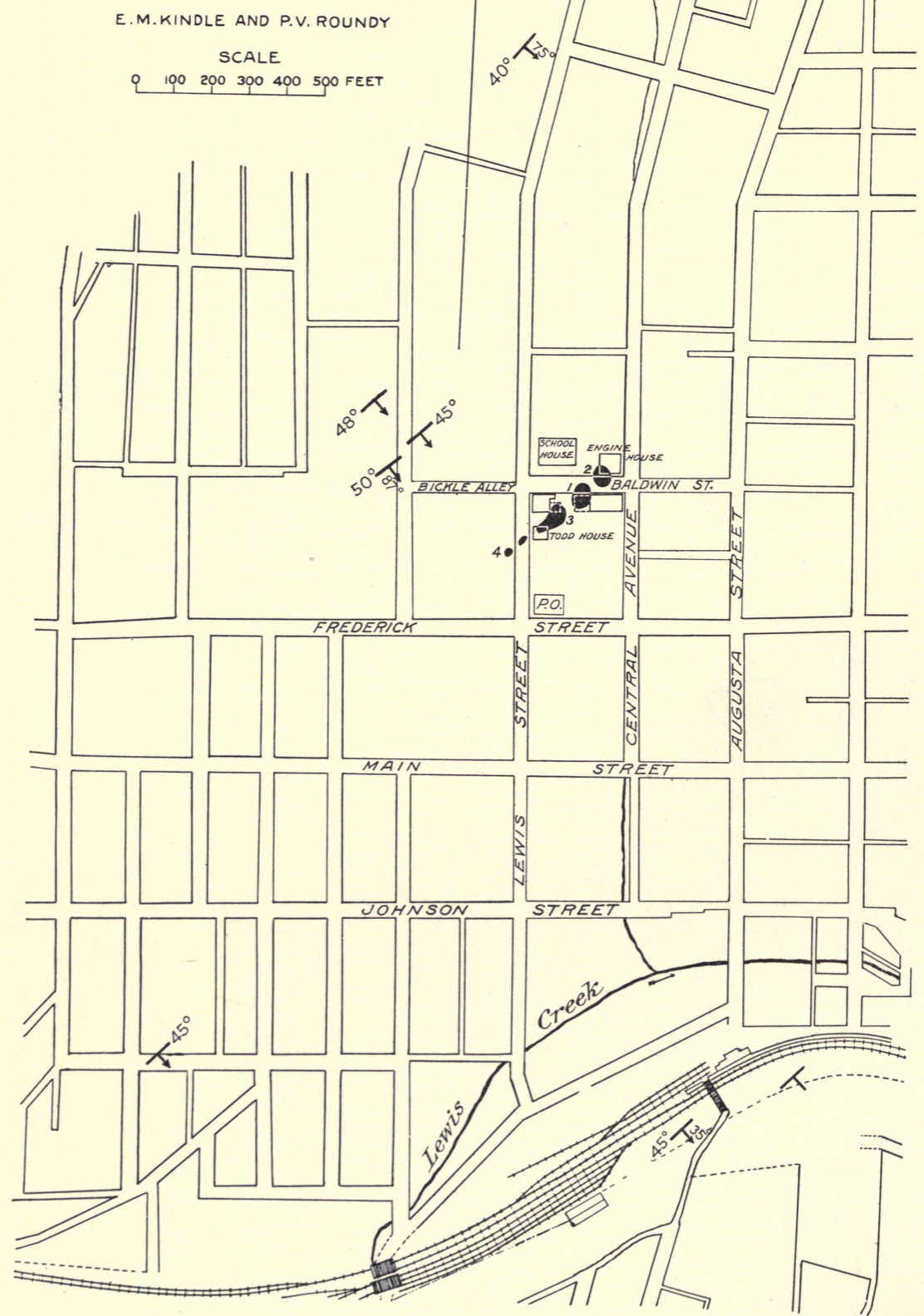


\title{
PROCEEDINGS
}

OF THE

\section{WASHINGTON ACADEMY OF SCIENCES}

Vol. XIII, No. 2, PP. 35-49. Pls. I-V. MaY I5, I9II.

\section{THE COLLAPSE OF RECENT BEDS AT STAUNTON, VIRGINIA $^{1}$}

\author{
By EDWARD M. KINDLE
}

U. S. Geological Survey

During the month of August, r9ro, a series of cavernous openings in the ground was developed in the central part of the city of Staunton, Va. These have been widely described in the daily press as the "Staunton cave-in" (Pls. II-V). The first three openings to appear have been described by Mr. F. B. Van Horn, ${ }^{2}$ of the U. S. Geological Survey. Since the publication of Mr. Van Horn's paper additional caving, and the completion of a series of drill holes by the city engineer to determine the limits of the solid bed rock, have shown more fully some of the essential facts relating to the character and direction of the underground channel responsible for the caving. Some record and discussion of these additional data and of the writer's geological observations made during a visit to the scene of the caving seems desirable. The underground stream involved in the "cavein" illustrates in its direction and development certain controlling factors to which attention will be invited in the course of the discussion, which are absent in the case of most of the underground streams familiar to the writer.

The city of Staunton is situated in a limestone region, being underlaid by the Shenandoah limestone of Cambro-Ordovician age. This

1 Published by permission of the Director of the U. S. Geological Survey.

${ }^{2}$ Engineering News, Sept. I, Igro.

Proc. Wash. Acad. Sci., May, rgr r. 
limestone has a thickness of not less than fifteen hundred feet, ${ }^{3}$ and owing to inclination of its strata probably extends several times that depth below the surface at Staunton. In this, as in most other limestone regions, subterranean streams play an important rôle in the drainage system. In the Carboniferous limestone region of Kentucky the location of hundreds of sub-surface stream channels is marked by caves mouths and sink holes. "In three counties in the vicinity of Mammoth Cave, over five hundred caves are known to exist.' '4 In considerable areas with which the writer is familiar in the limestone region of southern Indiana, more than 90 per cent of the rainfall is carried off by underground streams. Such streams collect the surface waters largely through the agency of irregular hopper-shaped depressions called limestone sinks or sink holes. In the earliest stage of the development of a sink hole the rainwater seeps through a crevice or joint in the limestone to a lower level. Gradually the passage way thus begun increases in size. At the same time the corrosion of the limestone goes on at the surface rather more rapidly in the immediate vicinity of the crevice than elsewhere. This solvent action of the surface waters, either alone or in conjunction with the breaking down of cavern roofs, in time develops the inverted cone-shaped depressions so characteristic of most limestone regions. The limestone sinks, though apt to be irregular in shape, generally approach more or less closely a circular outline at the top. In the Shenandoah valley these depressions generally attain a depth of from 20 to 80 feet and a width of from 60 to 300 feet.

It happens not infrequently that the outlets connecting the bottom of the sink hole with the subterranean stream become choked up and the sink becomes a pond or small lake. Nearly all ponds in limestone regions have had this origin. Such a pond, if the outlet at the bottom remains closed for a sufficiently long period, eventually becomes silted up or filled with marl and is transformed into a marsh, and sometimes even into dry land, through the complete filling of the depression and the reëstablishment of surface drainage. Such a cycle is liable to be interrupted at any time through adven-

${ }^{3}$ Folio U. S. Geol. Surv., No. 14.

' Caves and cave formations of the Mitchell limestone; F. C. Greene, Proc. Ind. Acad. Sci., I908, p. 176 . 
titious reopening of the outlet. In such a case the limestone sink resumes its original function of catch-basin for surface waters.

It happens that a small portion of the central part of the town of Staunton is located on a tract of land which has passed through the geologic cycle outlined above. The reopening and enlargement of the original outlets of the limestone sink which was the forerunner of the marl bed underlying this part of Staunton, led to the caving of the soft marl and gave to the residents of the city their first knowledge of the presence of this subterranean stream. The caved area lies near the lower end of a small valley traversed by one of the minor tributaries of Lewis Creek. This stream has been confined to a conduit of masonry throughout most of the lower part of its course in the city. At, and above the caved pits (Pl. I), the valley has a very low grade for half a mile or more and is nearly flat in cross-section for a width of three to five hundred feet. On both sides of this comparatively flat area the land rises one hundred feet or more in gentle hill slopes, showing frequent outcrops of the underlying limestone. In the bottom of the valley the limestone is buried nearly everywhere by several feet of superficial deposits of clay and marl. A short distance below the caved holes the grade of the valley is very much steeper than above. In fact the abrupt change of grade here would probably justify the use of the term "hanging valley" for the small valley near the lower end of which the superficial beds collapsed. Previous to the accumulation of the marl beds it had evidently been a closed valley. The abrupt change in the grade of the valley is undoubtedly due to the diversion of the water of the valley stream to a subterranean stream prior to the accumulation of the twenty to sixty feet of clay and marl which now forms the bottom above the abrupt grade. This diversion must have been through limestone sinks which developed in the vicinity of the holes recently caved in the marl beds. At some remote period outlets to the limestone sinks were closed and a large pond occupied the portion of the valley above Frederick street. The great numbers of freshwater shells in the marl beds afford indisputable evidence of the pond conditions under which the marls accumulated. It was during this stage in the history of the valley that the soft marl and clay beds were deposited above the temporarily closed subterranean channel, a superposition which brought 
disaster to a portion of the town which was eventually built upon them.

In company with Mr. P. V. Roundy the writer visited Staunton about one week after the crater-shaped openings began to develop. The following account of the development of the first three is based upon information furnished by Mr. C. E. Ashburner, City Engineer, and the account published by the Staunton Spectator. The facts regarding the last of the series to develop were furnished by Mr. J. Yost on whose property it occurred.

The initial caving occurred on the morning of August II. The occupants of a building on the south side of Baldwin street "heard a crash as if under their feet and suddenly the building shook and the pavement sank about 4 feet." The photograph (Pl. II, fig. I), shows this hole in this first stage of development. After its sudden beginning this first break progressed gradually. "The sinking of the ground continued constantly and in less than an hour it had sunk Io feet and the radius of the cave-in was 30 feet. Every now and then the dust would rise, showing that fresh caving was going on." Near the center of the ground included in the first break stood a tree 25 feet in height. "In less than two hours this tree had entirely disappeared." A few hours later the lateral enlargement of this first break carried down a two-story house about 25 by 35 feet in dimensions. Like the tree, this house passed out of sight in the cavernous opening. This building is shown in Pl. II, fig. I. About two hours after the first break a second occurred on the opposite side of Baldwin street and diagonally across from it (Pl. I). It is described as a sudden break which was accompanied by a loud report. It was at first a hole about 4 feet square in the pavement directly in front of the fire engine house. This increased by lateral caving at irregular intervals until it reached nearly across the street in one direction and under the fire engine house in the other, resulting in the ultimate destruction of the building. This second hole is shown in the foreground of Pl. II, fig. 2.

A few hours after the first break appeared, the third and largest of the holes began to develop about 75 feet to the southwest of the first Baldwin street hole. Its dimensions at the top were about 60 by 90 feet. This third slip of the ground carried with it three trees and a portion of a dwelling. The top of one of these trees 
which later completely disappeared is seen in Pl. III. The major part of one of the foundation walls of a house occupied by Mr. Todd went down with this break. Pl. V shows the character of the crevice in the limestone into which the engulfed materials disappeared as seen under the Todd house. For a short time after the caving began no water could be seen in the chasm but it rose gradually until, at the time of the writer's visit, it stood within 23 feet of the surface of ground, or almost at the top of the limestone channel seen in Pl. IV. The rate of inflow into this and the adjacent "cave-ins" (Pl. I), Nos. I and 2, is estimated at 40 gallons per minute by Hon. J. Yost. The depth of the cavern into which the superficial deposits have slumped has been shown by sounding to be at one point at least I 50 feet.

With the development of the third chasm caving ceased, save for occasional slumping of the walls, for more than two weeks. On August 27, however, a fourth opening appeared on the opposite side of Lewis street from the third hole, on the grounds of Mr.Yost. This hole was cistern-shaped, from Io to 12 feet in diameter and 18 deep. Still later an artificial excavation about 20 feet in width was made by the city across Lewis street over the line of the crevice opening into the cavern below for the purpose of arching it. Except for the slumping of one of the sides of this excavation in which a workman lost his life, no caving has occurred since that of August 27 .

The openings in the streets have been filled in after archirg the walls of the limestone crevice leading to the cavern below with concrete. On the property of Mr. Yost a cement arch was extended the entire length of the area disturbed by the caving. The work on the Yost property was accomplished without any surface excavation, it being carried out by tunneling over the line of the limestone crevice from the base of a shaft. This was sunk on the inner side of the "cave-in" on the Yost property to a depth of 44 feet. The excavation showed the limestone walls to be separated by an average width of 3 to 4 feet, the space narrowing downwards. This space was filled by tough, red clay. The width of the open interval between the limestone walls in hole No. 3 (Pl. I) is evidently much greater than this if we judge from the size of the trees and house which were engulfed. The only "cave-in" which still remains open 
is hole No. 3 on the Wilson property. On account of the attempt which was made to save the Todd house, which stands partly over this hole, by building a cement pillar foundation on the limestone below the marl beds, the water was prevented by pumping from rising to its normal level till recently. Since pumping has ceased the water has risen to within 6 feet of the surface in this hole.

The section exposed by the slumping of the soft beds into the cavernous limestone shows at the top I to 4 feet of dark brownish earth and clay. Below this is a bed which is mainly an ash-gray marl containing great numbers of minute fresh water shells. Some beds of yellow clay are interstratified with the marl. These marly beds have a thickness of from 20 to 50 feet. The well at the ice plant is reported to have passed through about I 2 feet of marl underlain by I4 feet of clay. The shaft on the Yost property is reported tohave penetrated only clay. Previous to caving the soft marl appears to have been prevented from slumping into the limestone channel by a tightly packed tough limestone clay. A small collection of shells was obtained from the marl beds by the writer. These have been determined by Dr. Paul Bartsch who has furnished the following list of the species represented:

Bythinella nickliniana Lea

Planorbis bicorinatus Say

Planorbis parvus Say

Pisidium sp.?

These all represent living species which are common to the streams and ponds of the southeastern states, thus indicating the postPlistocene or recent age of the beds.

A question of primary geologic as well as practical interest in connection with the caving is the direction followed under the town by the underground stream or cavern which is responsible for the caving. A brief examination of the bed rock stratigraphy in the vicinity of the caved area suggests that the underground course of this stream or cavern may be determined from stratigraphic data within the probable limits of future caving. The basis of this deduction will appear from a brief statement of the general factors controlling underground erosion in limestones and the particular factors which are chiefly effective in this case. It is a familiar fact that "the primary cause of motion in underground waters is gravi- 
tation." In a limestone region the movement of underground waters following the line of least resistance, is controlled almost entirely by joint planes and bedding planes. Where the rocks are tilted only moderately, or not at all, the joint planes generally exercise by far the greater influence on the movement of the underground waters and consequently upon the direction of subterranean channels. If, however, the beds are highly inclined or vertical, the surface waters have a strong tendency to descend along bedding planes, and joints have less influence in directing their movement. The efficiency of bedding planes in controlling the movement of underground waters is clearly stated as follows by Bain: "Bedding planes between strata are natural division planes and under the slightest stress or the action of solutions they afford openings of even greater extent than fault planes.",

When the joints intersect at various angles, as is frequently the case, the courses of the underground streams controlled by them will be irregular. Where the joints are uniform in direction the underground streams are likely to show a corresponding uniformity. This is illustrated by the caves in the Mitchell limestone in Indiana and Kentucky according to Mr. F. C. Greene. In this formation the joints have a general east and west and north and south direction. "Thus young caves and many which are older follow approximately straight north and south and east and west lines and have right-angled turns." 6

When, however, the direction of the movement of underground waters is controlled by nearly vertical bedding planes the horizontal flow will follow the direction of strike, and the resulting subterranean channels will necessarily follow in the main the strike of the beds. The subterranean channel disclosed by the caving marl and clay beds at Stauntonillustrates this type of stream. Examination of the strike and dip of the rocks in all directions within a radius of a few hundred yards from the caved area showed the beds to be inclined everywhere at a high angle, usually $75^{\circ}$ to $90 .^{\circ}$ (Pl. I.) The strike within the limits of the city has a uniform direct-

${ }^{3}$ Preliminary Report on the lead and zinc deposits of the Ozark region; H. F. Bain, C. R. Van Hise and G. J. Adams; 22nd Ann. Rept. U. S. Geol. Surv., Pt. II, rgor, p. 97 .

${ }^{\circ}$ Proc. Ind. Acad. Sci., I908, p. 178. 
ion, being almost due northwest and southeast. The well marked and highly inclined bedding planes and the absence of any very prominent system of joints afford the factors which, without any knowledge from observation, might be used to predict the probable direction of any underground stream or cavern. It was not surprising therefore, to find that the direction of the subterranean channel as exposed by the "cave-ins" coincided with the strike of the beds in its vicinity. Moreover, the sides of the limestone channel descended where they could be observed, at an angle and in a direction similar to that of nearby outcrops of the limestone and evidently conform rather closely to bedding planes. (Pl. V.)

At the time of the writer's visit all of the limestone channel which was exposed had a direction of N. $48^{\circ} \mathrm{W}$. The close agreement between the direction of the exposed channel and the strike of the rocks, and the evident predominant influence of strike and dip on underground drainage led the writer at the time of his visit to suggest to the city engineer that in all probability any future "caveins" would be on or very near the $48^{\circ}$ line passing through the first series of "cave-ins." This prediction seems to be verified by the alignment of a test drill hole which failed to reach bedrock, in Lewis street at the southwestern end of the earlier series of cavings, and by the last of the "cave-ins." Both of these were reported to be exactly on the $48^{\circ}$ line by the city engineer. ${ }^{7}$ As already stated the crevice thus located in Lewis street was uncovered by excavating and arched with concrete across the width of the street in order to forestall any possible further caving. Through the series of holes caved in the marl and the drill records we have definite knowledge of the position and direction of the subterranean channel for a distance of nearly 400 feet in a perfectly straight line (Pl. I). A large number of test drillings has been made on both sides of this line by the city engineer and the post-office authorities. All of these have struck bed rock between 20 and 50 feet below the surface except as noted above. These records, together with the fact that the exposed portions of the limestone crevice into which the clay and marl beds have slumped have in no case been outside the $48^{\circ}$ line, seem to demonstrate that the course of the underground

' Letter of Aug. 31, I9ro. 
stream coincides with the direction of the strike and is determined by it.

While the primary factors which lead up to the caving, or made it possible, are those which have been outlined it is less easy to state definitely what was the immediate cause of the caving. Various causes may lead to the reopening of the outlets of a silted-up limestone sink. Among these may be mentioned the burrowing of rodents or crawfish. A very small opening through the clay plug at the bottom of a closed sink hole might enlarge rapidly by the downward rush of ponded water. The gradual enlargement of the underground channel by solution of its walls and roof and the consequent breaking down of parts of its roof is in continuous though exceedingly slow operation in all caverns occupied by streams. The influence of a flooded condition of the underground channel, causing it to soften and erode rapidly any clay fillings in its roof might, in some cases, be effective in causing collapse of superficial beds. Another factor known to be effective in producing collapse in some regions is the general lowering of the ground water level. In the zinc district of southwestern Missouri, where limestone sinks, both filled and unfilled, are characteristic feature of the topography, Mr. C. E. Siebenthal informs me that extensive pumping in connection with mining operations is a generally recognized cause of the collapsing of caves as well as caving in of silted-up sink holes.

Having in mind some of the factors which may produce collapse as outlined above we may consider which, if any, has probably been the cause of caving at Staunton. One of the causes which has been suggested as the effective agency in producing the caving is the very heavy rain which occurred at Staunton shortly before the development of the caved holes. A flooded condition of the underground stream would tend undoubtedly to soften the clay filling of the limestone crevice as well as increase its weight. But this factor must have been active at intervals for centuries at least without producing caving, and probably can hardlybe regarded as more than a minor contributory cause at most. As an accessory to whatever may have been the primary cause of the initiation of caving there has been also the constantly present factor of vibration resulting from street traffic and the operation of a street car line across the line of caving. 
The small surface stream which flows through the caved valley and very near the "cave-in" which was first to develop has been suspected of being the cause of the trouble by some of the local students of the problem. The hypothetical manner in which the stream may be supposed to have accomplished the caving was by partial discharge of its water through some originally small adventitious outlet into the portion of the limestone cavern under Baldwin street. This flow, gradually increasing from a slight seepage at first to a discharge sufficient to have considerable erosive power on the marl, gradually undermined the street till the collapse resulted. The result of this first "cave-in," which may be considered to comprise the nearly adjacent holes Nos. I and 2 (Pl. I) was to block or dam the subterranean stream till it rose to the level of the marl and clay beds above the limestone. The water thus dammed may be supposed to have softened the superficial beds brought in contact with it and have lead to the successive development of holes Nos. 3 and 4 . The numbering of these holes on the map (Pl. I) corresponds to the order in which they developed. This hypothesis calls for a stream in the cavern flowing northeast. We are without definite information regarding the direction or the movement of water in the cavern, a current guage having failed to register any current. If this explanation of the caving were correct, careful examination of the artificial conduit of the stream in the vicinity of the caving should indicate the supposed diversion of water. A close examination of the conduit for this purpose by the city engineer, however, failed to show any such divergence. This hypothesis, therefore, appears to be supported by no ascertained facts, and it affords no explanation of the very suggestive sequence of events represented by the beginning of caving shortly after the starting of a high power pump nearby.

Another theory of the cause of the caving which requires consideration has been proposed by Hon. J. Yost. The well at the Smith ice-plant which is located about 150 feet from the line of caving, according to this theory, served to connect the strong stream near the bottom of the 800-foot well with the cavern under the "caveins" which previously had been empty or only partially filled with water. During the month which passed between the completion of the well and the installation of the roo-gallon pump, this cavern 
was filled from this new source through channels connected up by the well. As a result the clay and superficial beds over the limestone crevice leading to this newly filled reservoir were softened and weakened. As a consequence of this softening collapse resulted when the roo-gallon pump was started and the buoyant support of the water removed. The detailed evidence on which this explanation rests is best stated in Mr. Yost's words. In a letter to the writer December I2, I9I0, Mr. Yost says:

"He (Mr. Smith, owner of ice-plant well) states that at I25 feet he struck a stream of 5 gallons per minute, and the water rose in his well to within 24 feet of the surface. He then drilled down to 793 feet where a I 5 inch crevice was encountered and a stream. He continued his drilling to 801 feet. The water rose to within I 5 feet of the surface, or 9 feet higher than it had been before. The pump with the apparatus with which he drilled would only lift about 35 gallons. He installed another pump of between 50 and 65 gallon capacity, and with this, in 36 hours, reduced the water to 59 feet from the surface. For one month, pending the arrival of his new pump, the water was undisturbed and again rose to within I5 feet of the surface. The new pump had a capacity of roo gallons. This was operated for 108 hours and reduced the water in the well to roo feet from the surface. The first water drawn with the new pump was murky and continued so until the evening before the "cave-in," when it became clear. The next morning, when he noticed it, it was muddy, and about 9 o'clock, the first cave-in occurred. He was ordered to stop pumping and did so. Two days later, he tried to pump, but could not. A month later, the Superintendent of City Water undertook to clear out the well. He lowered a $\frac{3}{8}$ inch pipe to the 800 foot level and turned the city water (pressure about 70 pounds) into it. The discharge into the pipe was 3 gallons per minute. At the same time, Smith operated his pump and drew out about 8 gallons per minute-the 5 gallons from the I 25 feet opening plus the inflow of the city water. Apparently, the well at the 800 foot level was closed.

Smith then tried by the aid of air pressure and the pressure of the city water to open his well, but failed.

This record of the Smith well tends, in my mind, to substantiate the theory outlined in my letter to you on Monday. (That the stream encountered by Smith at the 800 foot level was diverted into the crevice under the Todd house). It shows that Smith never had roo gallons as supposed. What has bothered me, heretofore, has been to account for the supposed one hundred gallons from the well, when the flow from the Todd hole was scarcely one-third of that quantity. This explains it. The stream he struck at the 800 foot level could not have been more than 35 or 40 gallons. For more than a month after he struck this stream it probably emptied into the Todd hole. Thence it rose in the adjacent cavity and gradually saturated the roof to within 15 feet of the surface. 
The roof, thus weakened, gradually dropped down. This would account for the rumblings and mysterious noises noticed by the tenants of the Todd house for some time before the cave-in. Then, with his large pump, Smith drew that water off suddenly, and the roof gave away. Since that time the 35 gallons has been running into the Todd hole and this inflow and sudden evacuation caused the trouble.

I have endeavored to recall all of the circumstances and incidents connected with the trouble and nothing presents itself to me which negatives this theory, except one possible incident:

At the Clem Ice Factory, in the Valley 600 or 800 feet north of the school house, there are four shallow wells, ranging from 16 feet to 20 feet in depth. On the night following the slump, the pump in the deepest well failed to catch the water for an hour or one and a half hours. The same thing occurred the following night. Mr. Clem does not know whether or not any of the other walls were affected. I cannot attach great importance to this incident. The water was low for only $\mathrm{I} \frac{1}{2}$ hours at most and that may have been because he was drawing harder at that particular point. The fact that he dug four wells and uses them alltends to show that one of them could easily be temporarily exhausted."

As previously pointed out by Van Horn ${ }^{8}$ the data given by Mr. Yost seem to establish clearly the fact of direct connection between the stream tapped at 790 feet by the deep well and the water in the cavern under the "cave-in."

But the vital question in any interpretation of this relationship in explaining the caving is, did the water enter a previously empty cavern through the agency of the 80o-foot well, as Mr. Yost supposes, or did pumping the well empty the cavern which was previously full and which had never before been drained? It is the writer's view that the latter supposition is much the more probable. This probability is indicated by the fact that when the pumping ceased, which was utilized to lower the water in the "cave-ins" during the process of arching with cement the openings in the streets, and at the Todd house the water rose nearly to the surface in hole No. 3 . The rise was very rapid, 3 to 4 feet per hour, or about 35 gallons per minute, till it stood within ro feet of the surface. Above this point the rise was very much slower, about 5 to 6 feet per day, until it reached within 5 or 6 feet of the surface. "It was still rising at about this rate when pumping was resumed, and has since continued." (Letter from J. Yost, April 22.) If this water had entered the "cave-in" through the deep

8 Mining and Engineering News; Sept. I, rgro. 
well, as supposed by Mr. Yost, there should have been no such difficulty as is reported in pumping from the well after the caving ceased. This rise of water in the "cave-in" doubtless represents the original level of ground water previous to the caving. If this is true it follows that the roof of the cavern received a certain amount of support from the water which filled it previous to the caving. If we suppose the normal development of the cavern to have reached the point where the strength of the materials comprising its roof made them barely self-sustaining, the withdrawal of this hydrostatic support, however slight it may have been, combined with the rapid subsurface erosion of the marl which may have resulted, would have served as a trigger to start the collapse of the roof. Caving as a probable result of the withdrawal of such support is not only a theoretic but an observed fact in some mining districts, as will be seen from the following quotation from Smith and Siebenthal. ${ }^{9}$

"Where caverns are below the ground-water level and full of water the water helps support the weight of the roof. Where the balance is nicely adjusted and the roof is only just self-sustaining, if the waterbe withdrawn the cave will collapse. In a number of cases in the Joplin district such collapsing has followed the lowering of the ground-water level by pumping in the deeper mines. Without doubt many "natural caves" have in the geologic past resulted from the draining of caverns by elevation of the land and other causes, and have developed into closed valleys."

The above statement is substantiated by Bain ${ }^{10}$ who cites in the following quotation specific instances where collapse has resulted from the withdrawal of hydrostatic support in the lead and zinc region of southwestern Missouri.

"An interesting phenomenon of the Joplin caves is the fact that in them the weight of the roof is occasionally partly supported by the hydrostatic pressure of the water When the water is pumped out the roof may fall in. This occurred at the Budweiser mine at Tuckahoe. Near the

' Smith and Siebenthal; Joplin District Folio Missouri-Kansas; U. S. Geol. Surv., Bull. 148,1907 , p. 8.

${ }^{10}$ Preliminary report on the lead and zinc deposits of the Ozark region, H. F. Bain. With an introduction by C. R. Van Hise and chapters on the physiography and geology by George I. Adams, 22d Ann. Rep. Director U. S. Geol. Surv., Pt. II, Igor, p. I Io. 
Sand Ridge mine, at Aurora, great cracks similar in appearance to those formed by earthquakes developed in the summer of 1900 as pumping lowered the ground-water level. Near Carl Junction a section of railway track at one time sank, presumably as the result of pumping, in this instance some distance away."

Another example of this kind of collapse is furnished by the following account ${ }^{11}$ of a cave-in which occurred at Neck City, Mo., early in January of this year.

"A hole opened under the mill pond and a great elm tree was swallowed into the earth, in a natural cave so large that nothing remained visible of the tree when workmen arrived on the scene at 7 a.m.

"Some time between the night before and 7 o'clock yesterday morning the bottom of the pond went it, presumably as a result of water having been pumped from beneath, though no mine drifts exist beneath the cave.

"A tape line set down into the cave to a distance of 84 feet failed to touch bottom, though the nature of the hour-glass cave prevented a close scrutiny from the top."

From the cases cited above it will be seen that the caving of the roofs of natural caverns is a rather familiar phenomenon in the zinc region of Missouri where there appears to be no question regarding its dependence upon extensive pumping. In the light of these analogous cases it is hardly possible to ignore the suggestiveness of the fact that the caving at Staunton followed five days after the operation of the Ico-gallon pump at the ice plant began. That the pumping and caving bear the relation of cause and effect seems to the writer most probable.

The lowering of the water level in the cavern which resulted from the operation of the ice plant pump it is believed not only removed the buoyant support of the water from the beds forming the roof, but probably initiated strong downward currents through subsurface channels, thus carrying downward soft beds which had partially filled the interstices of the limestone roof and others above it, and which would otherwise have remained undisturbed. The intensified movement of downward trending waters through the marl resulting from the drainage of the limestone cavern below these beds may have developed fair-sized cavities in the marl

${ }^{11}$ Joplin (Mo.) News Herald, Jan. 15, I9r r. 
above the limestone roof of the cavern before the larger breaks in the limestone roof occurred. Such a temporary cavity in the marl superimposed upon the limestone cavern might, when it collapsed, precipitate tons of clay and marl with destructive effect upon the limestone roof which, under normal conditions, would have remained stable for ages. That the marl beds held abundant water for such streams, if their development were stimulated and an outlet provided by withdrawing the water from the cavern beneath a portion of the beds, is indicated by the fact that a pump at the Clem ice factory with a capacity of 50 gallons per minute draws its water from these beds. Desication resulting from the lowering of the ground water and the consequent shrinkage of the materials which filled the old outlets of the original sink hole may also have been a factor, though probably a minor one, in starting the caving. Consideration of all the available evidence which has been given appears to point to the lowering of the level of ground water by pumping as the most probable immediate cause of the caving. 



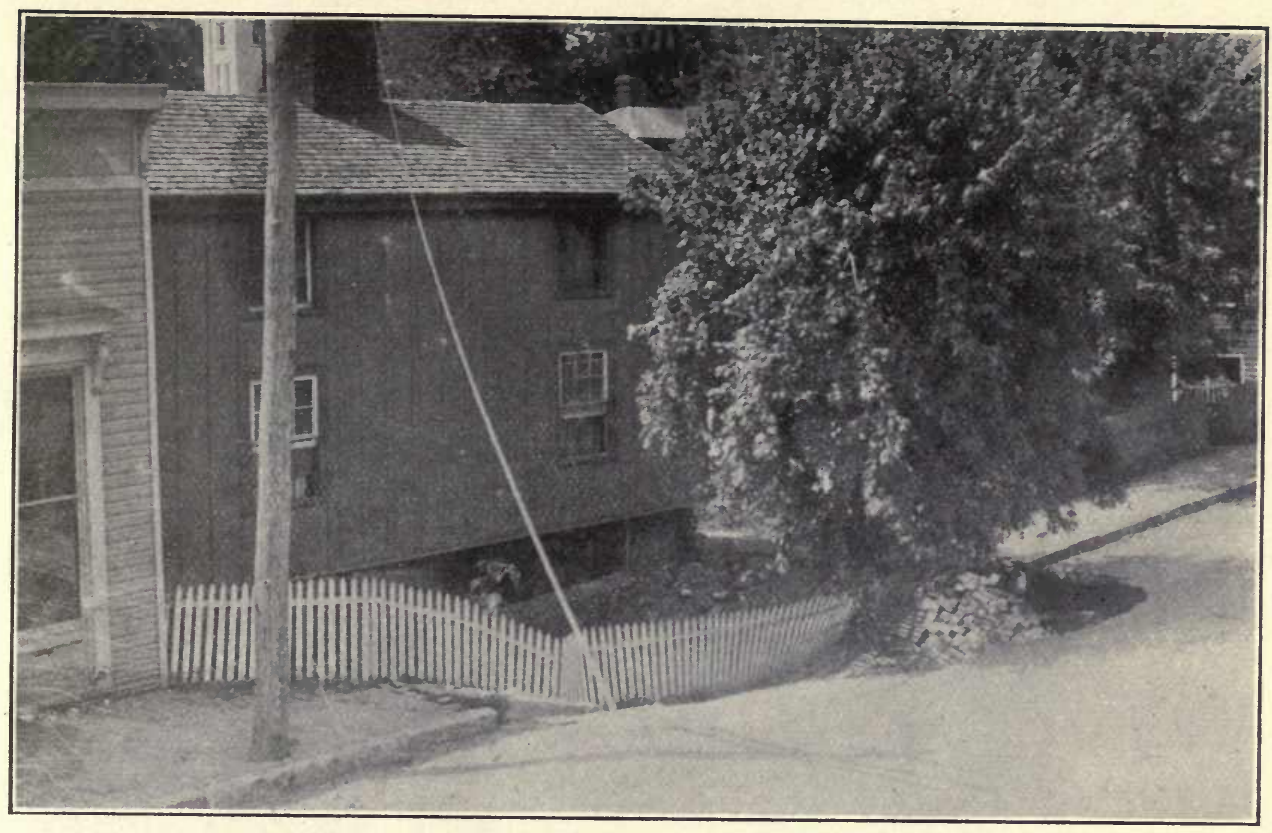

Fig. 1 Showing first stage of the caving and a house and tree which were engulfed.

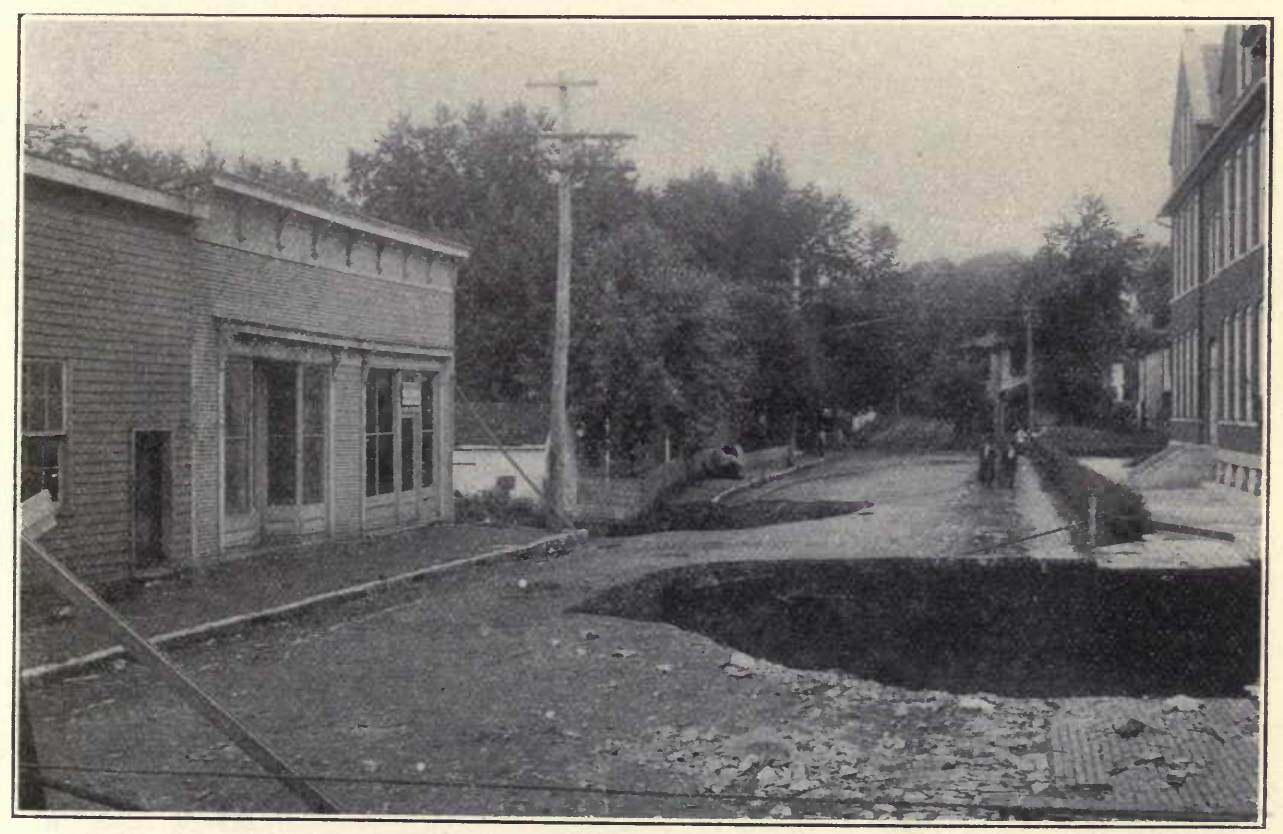

Fig. 2 View of two of the holes in Baldwin Street, taken after the disappearance of the house shown in Fig. 1. 



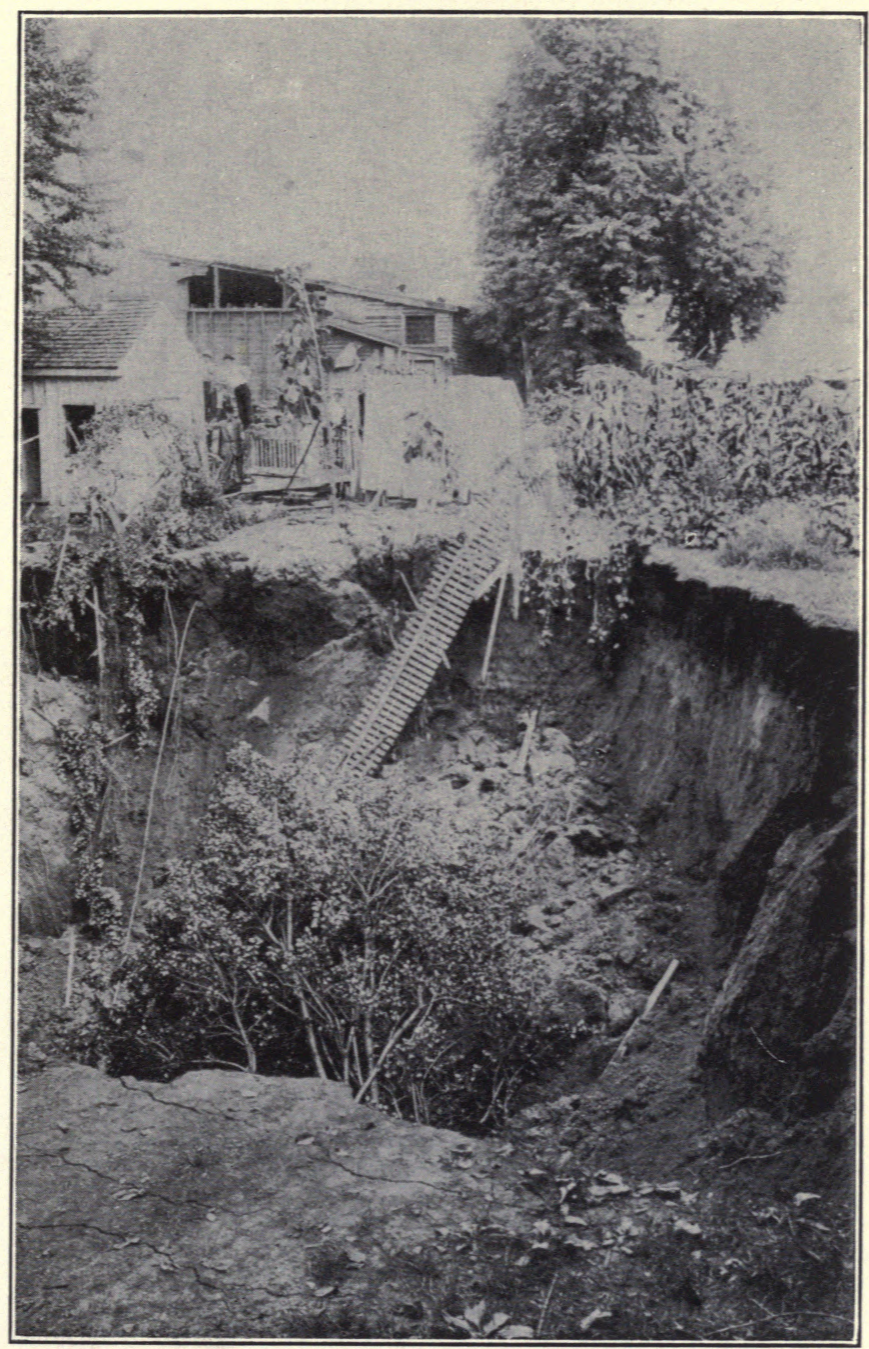

View showing an early stage of "cave-in" No. 3. 



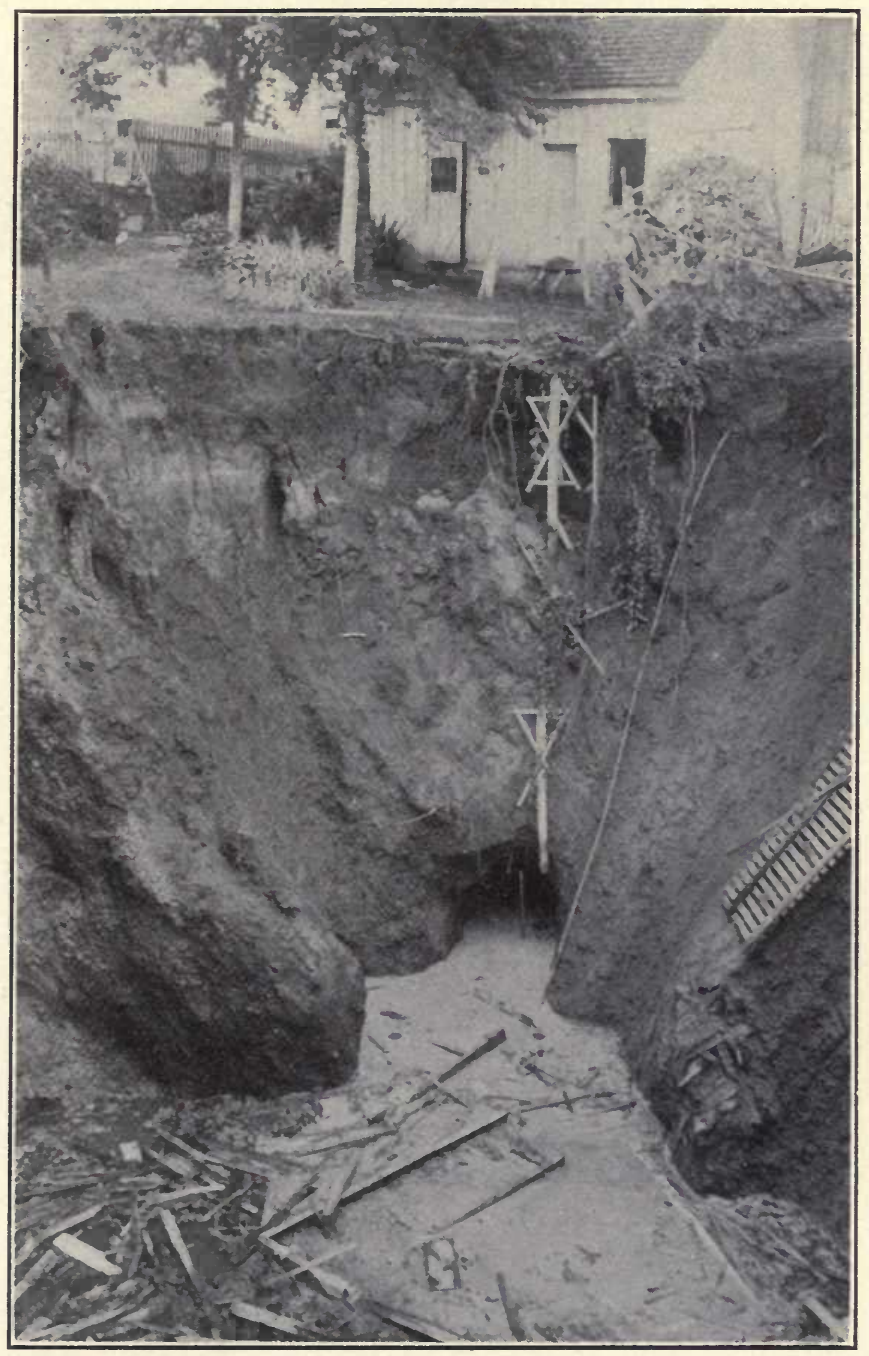

View of hole No. 3 after the disappearance of the shade tree seen in fig. 1, plate 2 , and the rise of the water. 



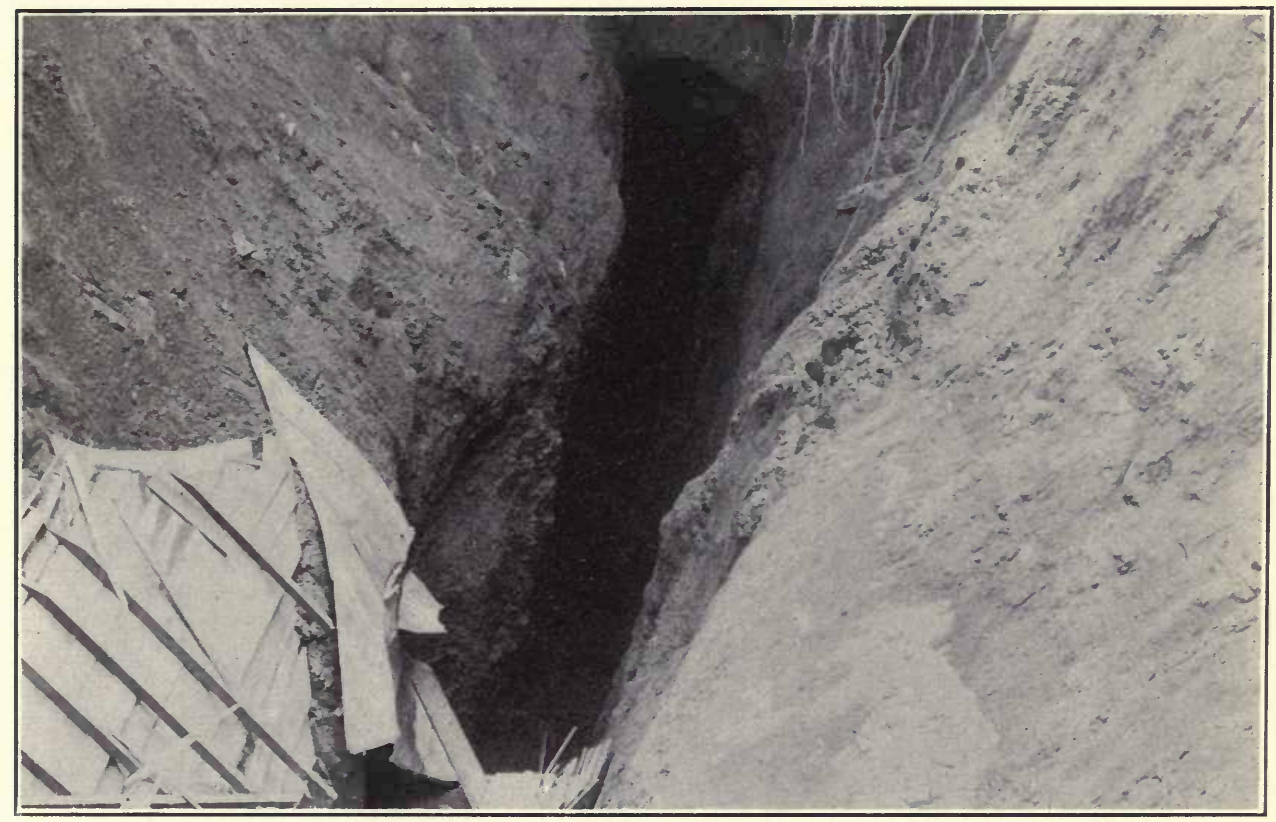

View showlng the crevice opening into the limestone cavern under the Todd house. 

THIS BOOK IS DUE ON THE LAST DATE STAMPED BELOW

AN INITIAL FINE OF 25 CENTS WILL BE ASSESSED FOR FAILURE TO RETURN WILL INCREAS THE DATE DUE. THE PENALTY DAY AND TO $\$ 1.00$ CENTS ON THE FOURTH OVERDUE. $\$ 1.00$ ON THE SEVENTH DAY

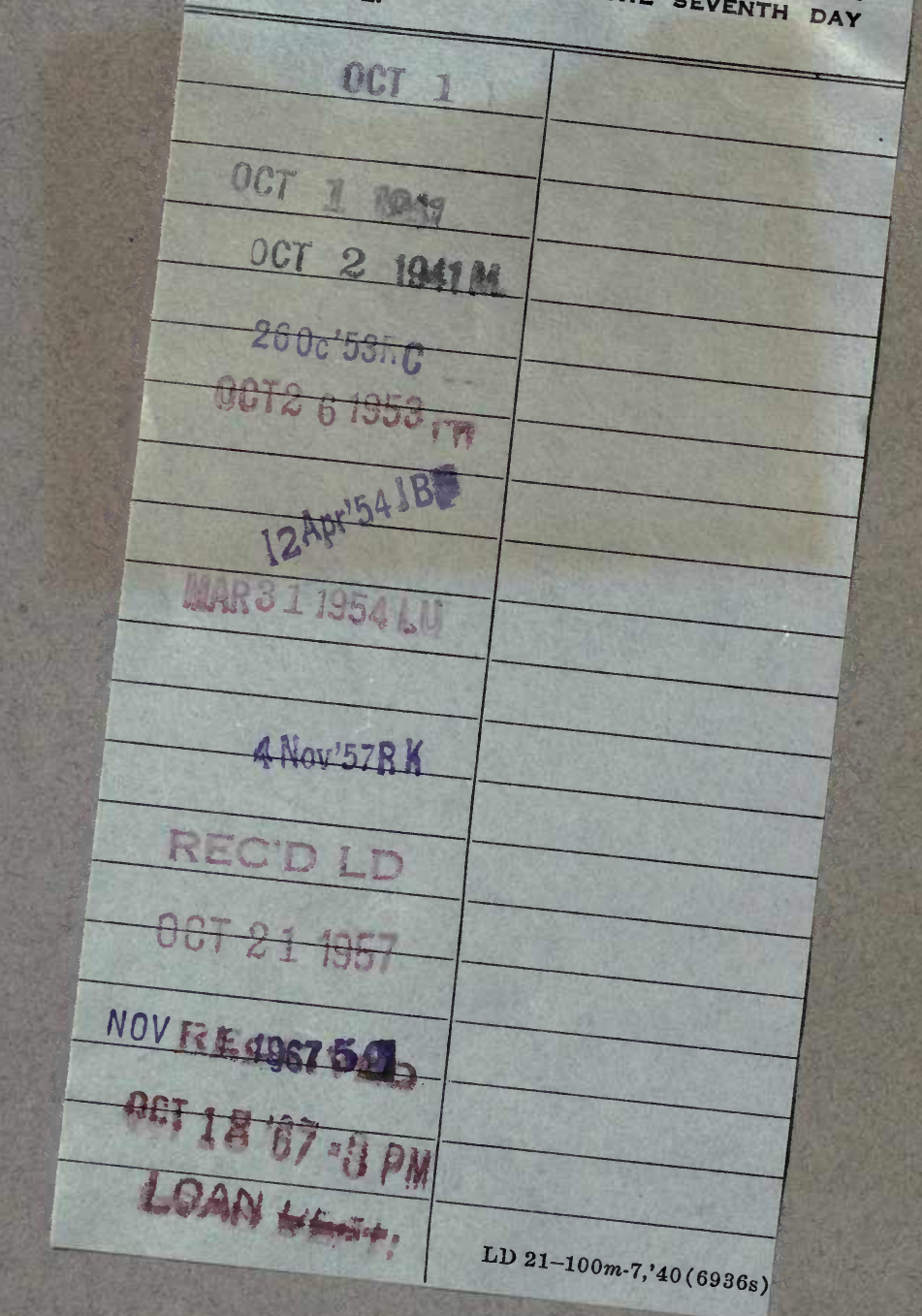



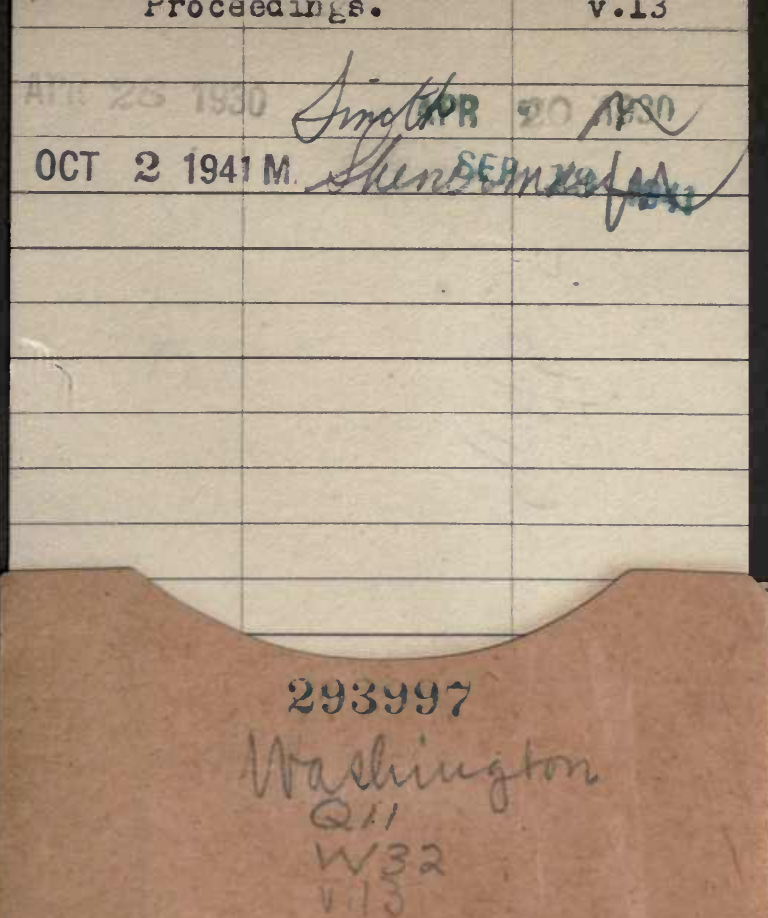

UNIVERSITY OF CALIFORNIA LIBRARY 


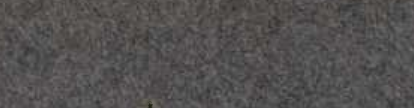

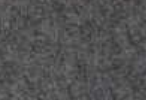

is 8 ing

a.

W.

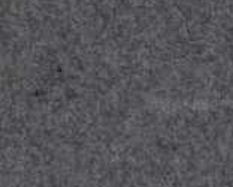

19.

6.

Th

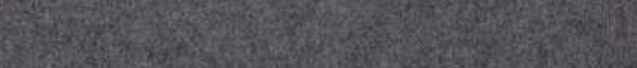

in

(i)

Whest

25.

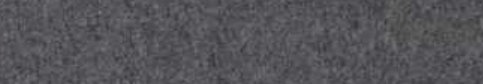

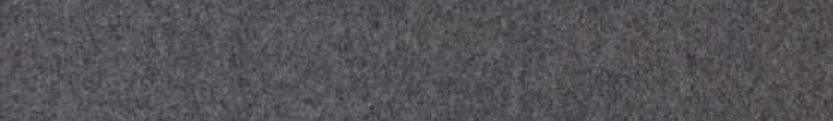

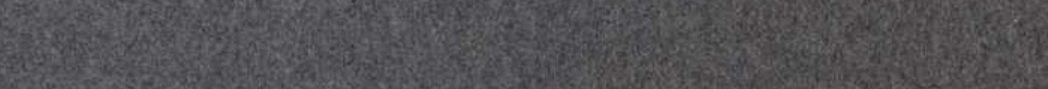

(2)

a.t.

(3.10)

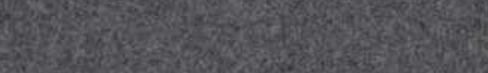

P.

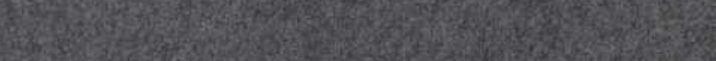

6.5.

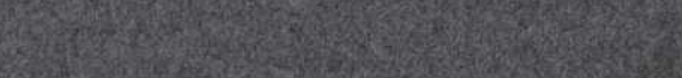

H.

W.

ivesto

Fin

(3)

1)

3.

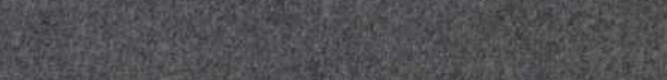

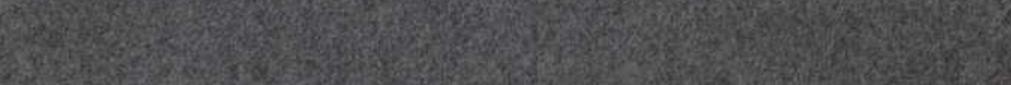

